\title{
Studies on the Formation of the Prothrombin-Converting Complex
}

\author{
By F. JOBIN* AND M. P. ESNOUF \\ Nuffield Department of Clinical Biochemistry (University of Oxford), \\ The Radcliffe Infirmary, Oxford
}

(Received 27 June 1966)

\begin{abstract}
1. It has been shown that factor $V$ accelerates the rate of conversion of prothrombin into thrombin by activated factor $X$, and that this activity does not depend on the presence of phospholipid. 2. Although the mechanism by which factor $V$ increases the rate of reaction is not clear, it seems unlikely that it is converted into an enzyme. 3. The rate of conversion of prothrombin by purified activated factor $\mathbf{X}$ and factor $\mathrm{V}$ was increased threefold in the presence of phospholipid, and it is suggested that the lipid acts by adsorbing the proteins on its surface and hence increasing the local concentration of the reactants.
\end{abstract}

It has been shown that the coagulant protein of Russell's-viper venom converts factor $\mathbf{X}$ from an inactive into an active form (Williams \& Esnouf, 1962 ; Esnouf \& Williams, 1962), and many authors have shown that mixtures of activated factor $X$, factor V, phospholipid and $\mathrm{Ca}^{2+}$ ions will convert prothrombin into thrombin. However, the mechanism of this last reaction remains obscure. One of the main obstacles to the determination of the reaction mechanism has been the absence of purified factor $\mathrm{V}$.

The preceding paper (Esnouf \& Jobin, 1967) describes the isolation and purification of factor $V$ and the purpose of the present paper is to investigate some aspects of the conversion of prothrombin by using purified reagents.

\section{MATERIALS AND METHODS}

Buffers. Sodium phosphate buffers were made by adding $\mathrm{NaOH}$ to $\mathrm{H}_{3} \mathrm{PO}_{4}$ solutions to give the required $\mathrm{pH}$. The molarity refers to the phosphate concentration.

Solutions of tris were adjusted to the required $\mathrm{pH}$ with $\mathrm{N}-\mathrm{HCl}$, and the molarity of the buffer refers to the final concentration of tris.

Bivalent metal solutions. The chlorides of the bivalent metals were dissolved in $0.02 \mathrm{M}$-tris to give $0.05 \mathrm{M}$ metal ion concentration. The $\mathrm{CaCl}_{2}$ was prepared by dissolving $\mathrm{CaCO}_{3}$ in the theoretical amount of $\mathrm{HCl}$. The solutions of the chlorides were adjusted with $\mathrm{HCl}$ to give $\mathrm{pH} 7 \cdot 5$.

Phospholipids. Inosithin was obtained from Associated Concentrates Inc., Woodside, N.Y., U.S.A. Dihexadecyl phosphoric acid was obtained from Albright and Wilson Ltd., London, S.W. 1. Phosphatidylcholine was prepared from fresh hens' eggs, according to Hanahan, Dittmer \& Warashina (1957). Phosphatidic acid was obtained from phosphatidylcholine by the method of Kates (1955).

\footnotetext{
* Present address: Hospital du Saint-Sacrement, Quebec, P.Q., Canada.
}

Thin-layer chromatography on Kieselgel G (Kuhn \& Lynen, 1965) showed that the phosphatidic acid contained only a trace of the lyso compound and contained no phosphatidylcholine.

The phospholipids were stored in solution in chloroform at $-20^{\circ}$; the phosphatidic acid was kept as the sodium salt. The molarity of the various phospholipid solutions was determined from an analysis of the phosphorus content (Bartley, 1953).

The emulsions of Inosithin were prepared by dissolving $500 \mathrm{mg}$. of Inosithin in $10 \mathrm{ml}$. of diethyl ether, and to this was added $10 \mathrm{ml}$. of $0.01 \mathrm{M}$-tris-HCl buffer, $\mathrm{pH} 8.4$. The ether was evaporated with a stream of $\mathrm{O}_{2}$-free $\mathrm{N}_{2}$. The emulsion was stored at $4^{\circ}$, and diluted for use in $0.02 \mathrm{M}$-tris$\mathrm{HCl}$ buffer, $\mathrm{pH} 7 \cdot 5$, containing $0 \cdot 14 \mathrm{~m}-\mathrm{NaCl}$.

Citrated bovine plasma. Ox blood was collected in $0 \cdot 1$ vol. of $0.1 \mathrm{M}$-trisodium citrate in a plastic container and then the blood was centrifuged to remove the formed elements.

Factor $X$-deficient bovine plasma. This was purchased from Thame Diagnostic Reagents Ltd., Thame, Oxfordshire.

Factor $V$. This was prepared and assayed as described by Esnouf \& Jobin (1967).

Preparation of $\mathrm{Xa}$.* Bovine factor $\mathrm{X}$ was purified as described by Esnouf \& Williams (1962), except that the final stage of differential ultracentrifugation was omitted. Factor X $(2.5 \mathrm{mg}$.) and $10 \mu \mathrm{g}$. of the coagulant protein of Russell's-viper venom dissolved in $0.15 \mathrm{M}-\mathrm{NaCl}$ buffered with $0.01 \mathrm{M}$-tris- $\mathrm{HCl}$ buffer, $\mathrm{pH} 7 \cdot 6$, were incubated at $37^{\circ}$ in the presence of $6 \mathrm{mM}-\mathrm{CaCl}_{2}$ and after $20 \mathrm{~min}$. the venom protein and $\mathrm{Xa}$ were separated by chromatography on ECTEOLA-cellulose. ECTEOLA-cellulose (Serva Entwicklungs Labor, Heidelberg, Germany), 5g., was suspended in $2 \mathrm{M}-\mathrm{NaCl}$ and the slurry was packed into a glass column $(1.8 \mathrm{~cm}$. diam.) to a height of $7.5 \mathrm{~cm}$. The cellulose was then equilibrated with $0.15 \mathrm{M}-\mathrm{NaCl}$ in $0.01 \mathrm{M}$-tris-HCl buffer, $\mathrm{pH} 7 \cdot 5$. The $\mathrm{Xa}$ and venom mixture was applied to the column in a volume of $2.5 \mathrm{ml}$. and the column was

* Abbreviations: ECTEOLA-cellulose, reaction product of epichlorohydrin, triethanolamine and cellulose; $\mathrm{Xa}$, activated factor $\mathbf{X}$. 
eluted at room temperature with $0.15 \mathrm{M}-\mathrm{NaCl}$ in $0.01 \mathrm{~m}$-tris-

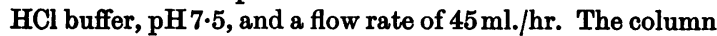
effluent was collected in $2.5 \mathrm{ml}$. fractions, and after 40 fractions, when all the venom protein had been eluted, the solvent was replaced by $0.4 \mathrm{M}-\mathrm{NaCl}$ in $0.01 \mathrm{M}$-tris- $\mathrm{HCl}$ buffer, pH 7.5, to elute the Xa. The eluate was mixed with an equal volume of glycerol and stored at $-20^{\circ}$.

Preparation of prothrombin. Partially purified bovine prothrombin was obtained during the preparation of factor X (Esnouf \& Williams, 1962). The protein fraction, which was eluted from DEAE-cellulose by $0.2 \mathrm{M}-\mathrm{NaCl}$, instead of $0.25 \mathrm{M}-\mathrm{NaCl}$, buffered with $0.02 \mathrm{M}$-sodium phosphate, $\mathrm{pH} 7 \cdot 0$, was concentrated by adsorption and elution from $\mathrm{BaSO}_{4}$, and further concentrated by ultrafiltration. The concentrated fraction was dialysed against $0 \cdot 10 \mathrm{M}-\mathrm{NaCl}$ in 0.02 $\mathrm{M}$-tris- $\mathrm{HCl}$ buffer, $\mathrm{pH} 7 \cdot 5$, and rechromatographed on DEAE-cellulose. The chromatogram was developed stepwise at room temperature with $0.02 \mathrm{M}$-tris-HCl buffer, $\mathrm{pH} 7 \cdot 5$, which contained $0.1 \mathrm{M}-, 0.22 \mathrm{M}-$ and $0.32 \mathrm{M}-\mathrm{NaCl}$. The prothrombin, which was eluted with $0.32 \mathrm{M}-\mathrm{NaCl}$, was concentrated by ultrafiltration and dialysed against $0 \cdot 14 \mathrm{M}-\mathrm{NaCl}$ buffered with $0.02 \mathrm{M}$-tris-HCl buffer, $\mathrm{pH} 7.5$.

The prothrombin prepared in this way did not contain any detectable amounts of factor $\mathrm{X}$ and factor $\mathrm{V}$ and only trace amounts of factors IX and VII were found.

Saline extract of brain. This was prepared as described by Biggs \& Macfarlane (1962).

Snake venom. Dried Russell's-viper venom was generously provided by the Wellcome Physiological Research Laboratories, Beckenham, Kent.

A sample of dried tiger-snake (Notechis scutatus scutatus) venom was kindly given by $\mathrm{Dr}$ B. Blombäck, Karolinska Institutet, Stockholm, Sweden, and further quantities were purchased from Koch-Light Laboratories Ltd., Colnbrook, Bucks.

Assay of Xa and Russell's-viper venom. The Xa assay is a modification of the method of Cole, Marciniak \& Seegers (1962). A portion (0.1 ml.) of an Inosithin emulsion (1.4 mg./ ml.) is added to $0.1 \mathrm{ml}$. of citrated bovine plasma, followed at 5 sec. intervals by $0.1 \mathrm{ml}$. of $0.025 \mathrm{M}-\mathrm{CaCl}_{2}$ and $0.1 \mathrm{ml}$. of the $\mathrm{Xa}$ sample, and the clotting time determined. The clotting time given by 40 units of $\mathrm{Xa}$ was $15 \mathrm{sec}$., that by 4 units of $\mathrm{Xa}$ was $32 \mathrm{sec}$., and 0.4 unit gave $68 \mathrm{sec}$. The blank time lay between 70 and 80 sec. A plot of the clotting time against various concentrations of $\mathrm{Xa}$ gave a straight line on $\log -\log$ paper. By definition a solution containing 100 units of $\mathrm{Xa} / \mathrm{ml}$. gives a clotting time of $11 \mathrm{sec}$. This assay can also be used to assay Russell's-viper venom by replacing the $\mathrm{Xa}$ by the venom. In instances when $\mathrm{Xa}$ had to be differentiated from the coagulant activity of Russell'sviper venom, the citrated bovine plasma was replaced by a factor X-deficient plasma.

Barium sulphate-adsorbed oxalated plasma. Oxalated plasma was stirred at room temperature for 15-20 min. with $\mathrm{BaSO}_{4}$ (100g./1.). The adsorbed plasma was recovered after centrifugation at $1000 \mathrm{~g}$ for $30 \mathrm{~min}$. (The $\mathrm{BaSO}_{4}$ was obtained from Judex, Fisons Scientific Apparatus Ltd., Loughborough, Leics.).

Assay of prothrombin. The $\mathrm{BaSO}_{4}$-adsorbed oxalated plasma $(0.1 \mathrm{ml}$.) was mixed with $0.1 \mathrm{ml}$. of the prothrombin sample diluted 1:10 with 0.02 M-tris-HCl buffer, $\mathrm{pH} 7.5$, containing $0.14 \mathrm{M}-\mathrm{NaCl}$. This was followed by $0.1 \mathrm{ml}$. of $0.025 \mathrm{M}-\mathrm{CaCl}_{2}$ and $5 \mathrm{sec}$. later by $0.1 \mathrm{ml}$. of Inosithin emulsion (1.4 mg./ml. in $0.14 \mathrm{M}-\mathrm{NaCl}$ buffered with $0.02 \mathrm{M}$-tris-HCl buffer, $\mathrm{pH} 7 \cdot 5)$ and containing $\mathrm{Xa}$ (1000 units/ml.). A standard curve was obtained by assaying dilutions of citrated human plasma between $1: 10$, which gave a clotting time of $9 \cdot 8 \mathrm{sec}$., and $1: 100$, which gave $42.5 \mathrm{sec}$, and plotting the log of clotting time against the log of the prothrombin concentration. When the prothrombin sample was replaced with saline, a blank time of 110 sec. was obtained.

Assay of prothrombin activator. A portion ( $0.1 \mathrm{ml}$.) of $0.025 \mathrm{M}-\mathrm{CaCl}_{2}$ was added to $0.1 \mathrm{ml}$. of factor V-deficient human plasma (Esnouf \& Jobin, 1967), followed after $5 \mathrm{sec}$. by $0.1 \mathrm{ml}$. of the sample of prothrombin activator, and the clotting time was recorded. In this assay an undiluted preparation of prothrombin activator, which gave a clotting time of 12 sec., gave a clotting time of 37 sec. when diluted 1:10. The dilutions were prepared by mixing the sample with $0.112 \mathrm{M}-\mathrm{NaCl}$ buffered with $0.02 \mathrm{M}$ tris-HCl buffer, $\mathrm{pH} 7 \cdot 5$, containing an Inosithin emulsion $\left(0.84 \mathrm{mg} . / \mathrm{ml}\right.$.) and $0.01 \mathrm{M}-\mathrm{CaCl}_{2}$ or $0.01 \mathrm{M}-\mathrm{MgCl}_{2}$, depending on the experiment. The blank clotting time was 200-250 sec. A plot of the clotting time against dilution of the activator gave a linear plot on log-log paper. The prothrombin activator was prepared freshly for each experiment and the concentration of $\mathrm{Xa}$ and factor $\mathrm{V}$ were those used in the particular experiment. In experiments in which $\mathrm{Xa}$ and factor $V$ were separated the assay was modified so that $0.1 \mathrm{ml}$. of an Inosithin emulsion $(1.4 \mathrm{mg}$. $/ \mathrm{ml}$.) was added to the factor V-deficient plasma, followed by the $\mathrm{CaCl}_{2}$ and prothrombin activator.

Assay of thrombin. This was as described by Biggs \& Macfarlane (1962).

Electrophoretic mobility of phospholipid micelles. This was measured in an apparatus for microelectrophoresis of small particles (Bangham, Flemans, Heard \& Seaman, 1958). Emulsions in $0.115 \mathrm{M}-\mathrm{NaCl}$ buffered with $0.03 \mathrm{M}$-tris- $\mathrm{HCl}$

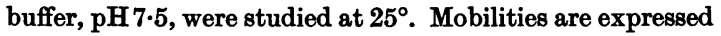
in $\mu / \mathrm{sec} . / \mathrm{v} / \mathrm{cm}$. at $25^{\circ}$.

\section{RESULTS}

Since prothrombin, $\mathrm{Xa}$ and factor $\mathrm{V}$ interact in the presence of a phospholipid emulsion, the interaction of the individual proteins with emulsions prepared from different phospholipids has been studied. These experiments were carried out by adding the protein in the presence and absence of bivalent metal ions to the phospholipid emulsion. After a $5 \mathrm{~min}$. incubation at room temperature or at $37^{\circ}$ the phospholipid was removed by centrifugation. The samples were centrifuged in an MSE Superspeed 40 centrifuge at $4^{\circ}$ in an $8 \times 10 \mathrm{ml}$. angle-head rotor at $85000 \mathrm{~g}$ for $20 \mathrm{~min}$. (the rotor was then allowed to come to rest without the brake).

After this the supernatant was decanted and the phospholipid pellet was resuspended in a volume of $0.112 \mathrm{M}$-sodium chloride containing $0.01 \mathrm{M}$ calcium chloride buffered with $0.02 \mathrm{M}$-tris-hydrochloric acid, $\mathrm{pH} 7.5$, equal to that of the original solution. The supernatant and resuspended phospholipid pellet were assayed for the coagulation factor in question.

The phospholipids which were used in these 
Table 1. Effect of calcium or magnesium ions on the adsorption of factor $V$ by emulsions of phosphatidic acid-phosphatidylcholine, phosphatidylcholine and Inosithin

$\begin{array}{lccc} & \text { Factor V distribution (\%) } \\ \text { Phospholipid emulsion } & \begin{array}{c}\text { Bivalent metal } \\ \text { ion (mM) }\end{array} & \overbrace{}^{\text {Supernatant }} & \text { Pellet } \\ \text { Phosphatidic acid-phosphatidylcholine }(1: 1) & \mathrm{Ca}^{2+}(10) & 92 & 8 \\ & \mathrm{Ca}^{2+}(10) & 90 & 10 \\ & - & 11 & 89 \\ & - & 10 & 90 \\ \text { Phosphatidylcholine } & \mathrm{Mg}^{2+(10)} & 85 & 15 \\ & \mathrm{Mg}^{2+}(10) & 85 & 15 \\ & \mathrm{Ca}^{2+}(7 \cdot 5) & 60 & 7 \\ \text { Inosithin } & \mathrm{Ca}^{2+(5 \cdot 0)} & 62 & 9 \\ & - & 26 & 24 \\ & - & 24 & 24 \\ & \mathrm{Ca}^{2+}(10) & 25 & 75 \\ & - & 25 & 24\end{array}$

experiments were divided into two classes: those active in coagulation tests and one which was inactive. Phosphatidylcholine was chosen as an example of an inactive phospholipid, and the active phospholipids were represented by Inosithin (mixed soya-bean phospholipids) and by a mixed phospholipid preparation containing equimolar proportions of phosphatidylcholine and phosphatidic acid.

The results obtained with factor $\mathrm{V}$ are given in Table 1. It will be seen that factor $\mathrm{V}$ is adsorbed from the supernatant by both the active and inactive phospholipids and except for Inosithin the adsorption was better in the absence of metal ions. The low recovery of factor $V$ from emulsions of phosphatidylcholine in the absence of $\mathrm{Ca}^{2+}$ may be because the protein is not transferred to active phospholipid surface in the assay.

These results suggest that the interaction of factor $\mathrm{V}$ with the phospholipid is not chargedependent, which is in contrast with the observations made when these experiments were repeated with $\mathrm{Xa}$ instead of factor $\mathrm{V}$.

In some experiments the phospholipid emulsion was replaced by a suspension of polystyrene latex particles, 0.126 $\mu$ diam. (Dow Chemical Co., Midland, Mich., U.S.A.). When citrated bovine plasma was used as the source of factor $V$, most of the activity was adsorbed by the particles. If pure factor $V$ was used instead of plasma the particles flocculated, which prevented any quantitative assessment of the degree of adsorption. Factor $\mathrm{V}$ also appeared to interact with Sephadex (Pharmacia Ltd., Uppsala, Sweden). Samples of factor $\mathrm{V}$ applied to columns of either Sephadex G-100 or G-200 were not eluted in the void volume of the column, as would be expected from the molecular weight, but were gradually recovered from the columns by continuous elution over a period of

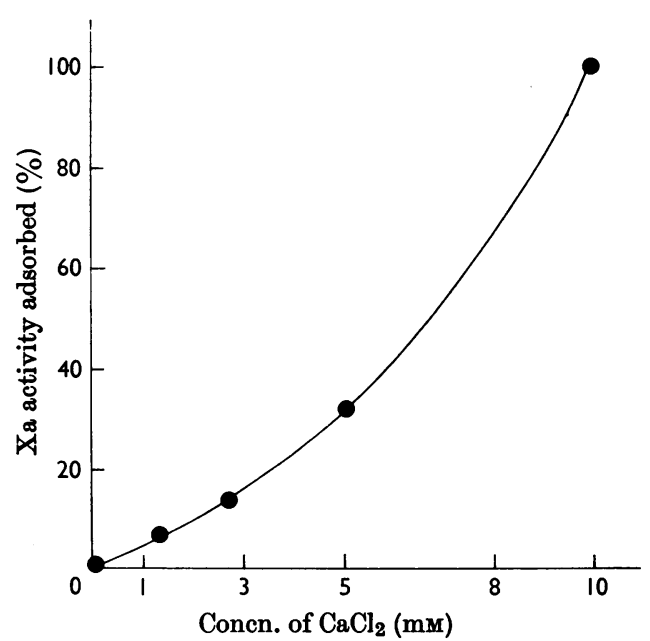

Fig. 1. Effect of $\mathrm{Ca}^{2+}$ concentration on the adsorption of $\mathrm{Xa}$ by Inosithin: 40 units of $\mathrm{Xa}$ and $1 \mathrm{mg}$. of Inosithin were made to final volume $1 \mathrm{ml}$. with $0.02 \mathrm{M}$-tris-HCl buffer, $\mathrm{pH} 7 \cdot 5$, and $\mathrm{CaCl}_{2}$ at the concentrations shown. After $3 \mathrm{~min}$. incubation at $37^{\circ}$ the Inosithin was removed by centrifuging at $85000 \mathrm{~g}$ for $15 \mathrm{~min}$. The pellet was resuspended in $1 \mathrm{vol}$. of $0.112 \mathrm{M}-\mathrm{NaCl}$ containing $0.01 \mathrm{M}$ $\mathrm{CaCl}_{2}$ in $0.02 \mathrm{M}$-tris- $\mathrm{HCl}$ buffer, $\mathrm{pH} 7 \cdot 5$, and assayed for Xa.

days. This phenomenon appeared to be independent of both solvent and temperature.

The adsorption of $\mathrm{Xa}$ by emulsions of Inosithin depended on the concentration of $\mathrm{Ca}^{2+}$ (Fig. 1). Moreover, the $\mathrm{Ca}^{2+}$ could be replaced by a number of other bivalent metal ions, as shown in Table 2. Particularly noteworthy is the result obtained with $\mathrm{Mg}^{2+}$, in the presence of which Xa was hardly 
Table 2. Effect of bivalent metal ions on the adsorption of Xa by Inosithin

$\begin{array}{ccc}\begin{array}{c}\text { Bivalent } \\ \text { metal ion }\end{array} & \begin{array}{c}\text { Optimum } \\ \text { molarity (mM) }\end{array} & \begin{array}{c}\text { Xa adsorbed } \\ (\%)\end{array} \\ \mathrm{Ca}^{2+} & 10 & 100 \\ \mathrm{Cd}^{2+} & 5 & 60 \\ \mathrm{Sr}^{2+} & 5 & 42 \\ \mathrm{Mn}^{2+} & 10 & 22 \\ \mathrm{Cu}^{2+} & 2 \cdot 5 & 18.5 \\ \mathrm{Ba}^{2+} & 10 & 11 \\ \mathrm{Ni}^{2+} & 10 & 3 \\ \mathrm{Co}^{2+} & 5 & 3 \\ \mathrm{Mg}^{2+} & 10 & 0.6 \\ \mathrm{None} & - & 0.5\end{array}$

Table 3. Effect of bivalent metal ions on the adsorption of Xa by a mixed emulsion of phosphatidic acidphosphatidylcholine (1:1)

Final concn. of metal ions was $5 \mathrm{~mm}$.

$\begin{array}{cc}\text { Bivalent } & \mathrm{Xa} \text { adsorbed } \\ \text { metal ion } & (\%) \\ \mathrm{Ca}^{2+} & 100 \\ \mathrm{Ba}^{2+} & 63 \\ \mathrm{Sr}^{2+} & 13 \\ \mathrm{Mg}^{2+} & 0.16 \\ \mathrm{None} & 0.02\end{array}$

adsorbed by the Inosithin emulsion, and as is shown in experiments described below $\mathbf{M g}^{2+}$ eluted $\mathrm{Xa}$ from emulsions that had previously adsorbed $\mathrm{Xa}$ in the presence of $\mathrm{Ca}^{2+}$.

Similar results were obtained when the adsorption of $\mathrm{Xa}$ was investigated in the presence of alkaline-earth metal ions by emulsions of equimolar proportions of phosphatidylcholine and phosphatidic acid (Table 3). It is noteworthy that in this case more $\mathrm{Xa}$ is adsorbed in the presence of $\mathrm{Ba}^{2+}$ than $\mathrm{Sr}^{2+}$.

When the adsorption of $\mathrm{Xa}$ was studied in the presence of $\mathrm{Ca}^{2+}$ by emulsions containing varying proportions of phosphatidylcholine and phosphatidic acid it was seen (Table 4) that the degree of adsorption of the protein can be correlated with the electrophoretic mobility of the micelles, and hence with the charge. However, it would appear that charge is not the only requirement, as is shown from the result obtained by using an emulsion containing a mixture of dicetyl phosphoric acid and phosphatidylcholine. The results suggest that the emulsions which had the highest activity in coagulation tests were those which adsorbed the most Xa.

The importance of the bivalent metal ion in the adsorption of $\mathrm{Xa}$ by the emulsions, and the effect
Table 4. Effect of surface charge on the adsorption of $X a$ by phospholipid micelles

Electrophoresis was carried out in $0.115 \mathrm{M}-\mathrm{NaCl}$ buffered with $0.03 \mathrm{M}$-tris-HCl buffer, $\mathrm{pH} \mathrm{7.5}$, at $25^{\circ}$. The incubation with $\mathrm{Xa}$ was performed at $37^{\circ}$.

$$
\begin{array}{ccc}
\text { Molar ratio } & \begin{array}{c}
\text { Mobility } \\
(\mu / \mathrm{sec} . / \mathrm{v} / \mathrm{cm} .)
\end{array} & \begin{array}{c}
\text { Xa adsorbed } \\
(\%)
\end{array}
\end{array}
$$

Phosphatidic acid/phosphatidylcholine

$\begin{array}{rlr}0: 100 & 0 & 3 \cdot 5 \\ 2 \cdot 6: 100 & 0 \cdot 3 & 9 \cdot 2 \\ 11: 100 & 1 \cdot 15 & 22 \cdot 0 \\ 25: 100 & 2 \cdot 12 & 25 \cdot 0 \\ 100: 100 & 3 \cdot 2 & 40 \cdot 0\end{array}$

Dicetyl phosphoric acid/phosphatidylcholine $\begin{array}{lll}20: 100 & 1 \cdot 72 & 4 \cdot 8\end{array}$

Inosithin

$2 \cdot 3$

100

Table 5. Elution of Xa from Inosithin emulsion by citrate and magnesium ions

\begin{tabular}{lc}
\multicolumn{1}{c}{ Eluent } & $\begin{array}{c}\text { Residual Xa activity } \\
\text { left on Inosithin }\end{array}$ \\
Control $\left(0 \cdot 01 \mathrm{M}-\mathrm{CaCl}_{2}\right)$ & $(\%)$ \\
$0 \cdot 001 \mathrm{M}-$ Sodium citrate & 100 \\
$0 \cdot 01 \mathrm{M}-\mathrm{Sodium}$ citrate & $7 \cdot 5$ \\
$0 \cdot 1 \mathrm{M}-\mathrm{MgCl}_{2}$ & $0 \cdot 85$ \\
& 0.92
\end{tabular}

of $\mathrm{Mg}^{2+}$, is clearly shown in Table 5. In these experiments the phospholipid emulsions were resuspended first in 1 vol. of $0.02 \mathrm{M}$-tris-hydrochloric acid buffer, $\mathrm{pH} 7 \cdot 5$, containing $0.01 \mathrm{M}$ calcium chloride, $0.001 \mathrm{M}$ - or $0.01 \mathrm{M}$-sodium citrate, or $0.1 \mathrm{M}$-magnesium chloride, and after this the mixtures were centrifuged and resuspended as in the previous experiments.

The adsorption of prothrombin in the presence and absence of metal ions by emulsions of Inosithin, and emulsions containing equimolar proportions of phosphatidic acid and phosphatidylcholine, or dicetyl phosphoric acid and phosphatidylcholine in the molar ratio $1: 4$, was similar to that found with Xa (Table 6). Thrombin was not adsorbed by any of the phospholipid emulsions used either in the presence or in the absence of metal ions.

From the results which have been obtained so far it is apparent that $X a$, factor $V$ and prothrombin are adsorbed by the phospholipid emulsions which are also active in coagulation, and it is likely that their interaction takes place on the surface of the phospholipid micelles. Two mechanisms can be envisaged for the interaction of these proteins that results in the formation of thrombin: in Scheme $\mathrm{l}(\mathrm{A})$, the existence of ' $\mathrm{Va}$ ' is postulated. By this Bioch. 1967, 102 
Table 6. Adsorption of prothrombin by emulsions of Inosithin, and mixed emulsions of phosphatidic acid-phosphatidylcholine or dicetyl phosphoric acid-phosphatidylcholine

\begin{tabular}{|c|c|c|c|c|}
\hline \multirow[b]{2}{*}{ Emulsion (molar ratio) } & \multirow{2}{*}{$\begin{array}{l}\text { Bivalent metal } \\
\text { ion }(\mu \mathrm{M})\end{array}$} & \multicolumn{3}{|c|}{ Prothrombin activity (\%) } \\
\hline & & Supernatant & Pellet & Total \\
\hline Inosithin & $\begin{array}{l}\mathrm{Ca}^{2+}(5 \cdot 0) \\
\mathrm{Ca}^{2+}(10) \\
\mathrm{Ba}^{2+}(10) \\
\mathrm{Sr}^{2+}(10) \\
\mathrm{Mg}^{2+}(10) \\
\text { None }\end{array}$ & $\begin{array}{l}47 \\
42 \\
69 \\
66 \\
86 \\
38\end{array}$ & $\begin{array}{c}34 \\
58 \\
40 \\
37 \\
1 \cdot 4 \\
1 \cdot 3\end{array}$ & $\begin{array}{c}81 \\
100 \\
109 \\
103 \\
87 \cdot 4 \\
39 \cdot 3\end{array}$ \\
\hline Phosphatidic acid-phosphatidylcholine $(1: 1)$ & $\begin{array}{l}\mathrm{Ca}^{2+}(10) \\
\mathrm{Mg}^{2+}(10) \\
\text { None }\end{array}$ & - & $\begin{array}{l}1 \cdot 7 \\
1 \cdot 3 \\
0 \cdot 3\end{array}$ & $\frac{-}{-}$ \\
\hline Dicetyl phosphoric acid-phosphatidylcholine (1:4) & $\mathrm{Ca}^{2+}(5)$ & - & $7 \cdot 0$ & - \\
\hline
\end{tabular}

$$
\begin{aligned}
& \mathrm{Xa}+\mathrm{V} \underset{\text { phospholipid }}{\stackrel{\mathrm{Ca}^{2+}}{\underset{\mathrm{Ca}}{2+}} \mathrm{Va}} \quad \mathrm{Xa}+\mathrm{II} \frac{\mathrm{Ca}^{2+}+\mathrm{V}}{\text { phospholipid }} \mathrm{IIa} \\
& \mathrm{Va}+\mathrm{II} \underset{\text { phospholipid }}{\stackrel{\text { IIa }}{ }}
\end{aligned}
$$

Scheme 1. Two possible mechanisms for the activation of prothrombin (II) by mixtures of $\mathrm{Xa}$, factor $\mathrm{V}$ and phospholipid.

is meant that factor $\mathrm{V}$ is a zymogen and is converted into an active enzyme by the action of $\mathrm{Xa}$. Va would then react together with $\mathrm{Ca}^{2+}$ and phospholipid to convert prothrombin into thrombin. In the Scheme $1(B)$ factor $V$ is considered to act as a 'catalyst' together with phospholipid and $\mathrm{Ca}^{2+}$ for the enzymic conversion of prothrombin by Xa. The experiments which will now be described are an attempt to demonstrate by which mechanism prothrombin is converted into thrombin.

In the first instance it was not possible to demonstrate any time-consuming reaction between $\mathrm{Xa}$ and mixtures of factor $\mathrm{V}, \mathrm{Ca}^{2+}$ and phospholipid over a wide range of concentrations; if there was, it went to completion within 20 sec. This was the minimum time required for the assay of the biological activity of the mixtures.

Secondly, no increase in esterase activity could be detected when $\mathrm{Xa}$ was added to mixtures of factor $\mathrm{V}$, phospholipid and $\mathrm{Ca}^{2+}$ when tested against the following synthetic substrates: benzoylarginine methyl ester; toluene-p-sulphonylarginine methyl ester; acetyltyrosine ethyl ester ; lysine ethyl ester; leucine ethyl ester.

In the presence of $0.01 \mathrm{~m}$-calcium chloride, variations in the concentrations of factor $\mathrm{V}, \mathrm{Xa}$ or phospholipid in the reaction mixture influenced the amount of prothrombin-converting activity generated (Figs. 2, 3 and 4).

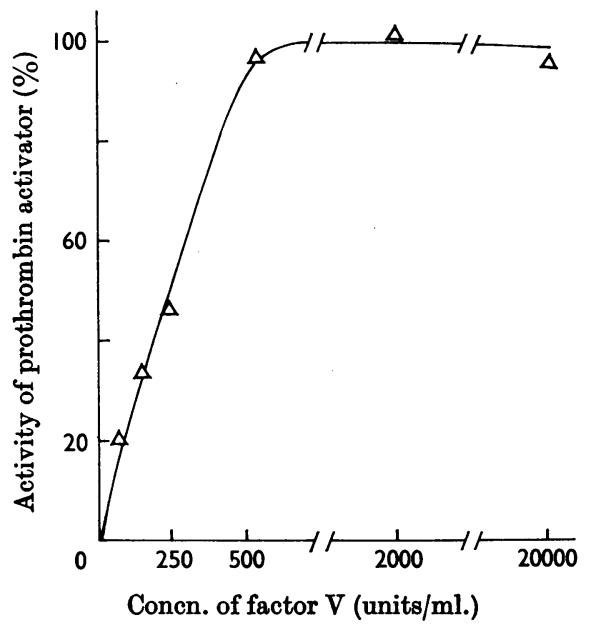

Fig. 2. Effect of the concentration of purified factor $V$ on the yield of prothrombin activator. Factor $V$ at the concentrations shown was incubated with 15 units of $\mathrm{Xa}$, $0.125 \mathrm{mg}$. of Inosithin and $6 \mathrm{mM}-\mathrm{CaCl}_{2}$ and the mixture made to final volume $1 \mathrm{ml}$. with $0 \cdot 112 \mathrm{M}-\mathrm{NaCl}$ buffered with $0.02 \mathrm{M}$-tris-HCl buffer, $\mathrm{pH} 7 \cdot 5$. After $3 \mathrm{~min}$. incubation at $37^{\circ} 0 \cdot 1 \mathrm{ml}$. samples were taken for the assay of prothrombin activator.

If $\mathrm{Va}$ is the substance that converts prothrombin into thrombin, then it should be possible to separate $\mathrm{Xa}$ from a mixture which will convert prothrombin, without affecting the prothrombin-converting activity. It has been mentioned briefly that $\mathbf{M g}^{2+}$ would displace $\mathrm{Xa}$ from phospholipid emulsions, and advantage has been taken of this effect to separate the components of the prothrombin activator. In these experiments Inosithin has been used throughout, since it gave stable and reproducible emulsions. $\mathrm{Xa}$, factor $\mathrm{V}$ and $\mathrm{Ca}^{2+}$ were 


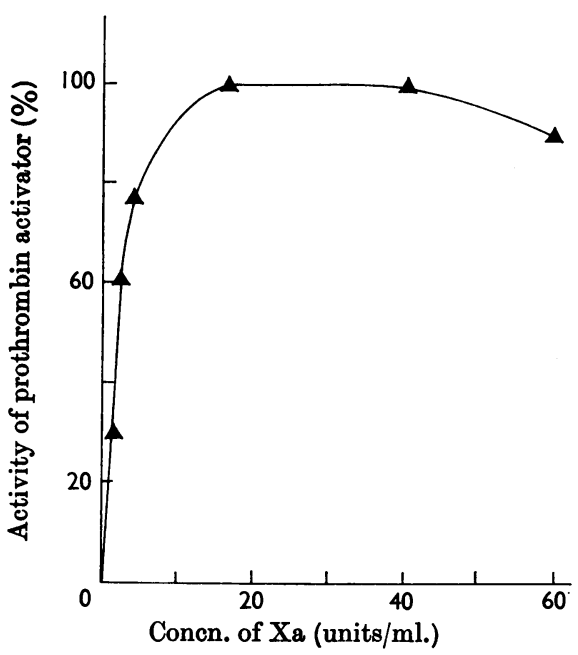

Fig. 3. Effect of the concentration of $\mathrm{Xa}$ on the yield of prothrombin activator: $\mathrm{Xa}$ at the concentrations shown was incubated at $37^{\circ}$ with 18 units of factor $V, 1 \cdot 25 \mu \mathrm{g}$. of Inosithin and $6 \mathrm{~mm}-\mathrm{CaCl}_{2}$ and the mixture was made to final volume $1 \mathrm{ml}$. with $0.112 \mathrm{M}-\mathrm{NaCl}$ buffered with $0.02 \mathrm{M}$-tris-HCl buffer, $\mathrm{pH} 7 \cdot 5$. After $3 \mathrm{~min}$. samples were taken for the assay of prothrombin activator.

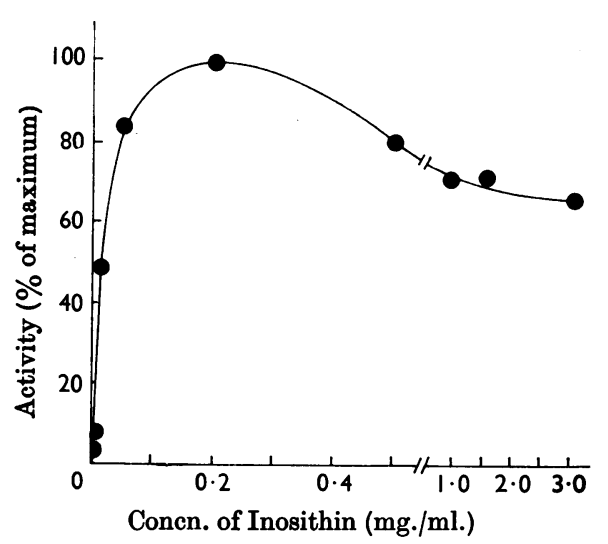

Fig. 4. Effect of phospholipid concentration on the yield of prothrombin activator. Inosithin at the concentrations shown was incubated at $37^{\circ}$ with 50 units of factor $V$, 9 units of $\mathrm{Xa}$ and $6 \mathrm{mM}-\mathrm{CaCl}_{2}$ and the mixture made to final volume $1 \mathrm{ml}$. with $0.112 \mathrm{M}-\mathrm{NaCl}$ buffered with $0.02 \mathrm{M}$ tris-HCl buffer, pH 7.5. After 3 min. samples were taken for the assay of prothrombin activator. In these experiments the factor V-deficient plasma was centrifuged at $75000 \mathrm{~g}$ for $25 \mathrm{~min}$. before incubation to minimize contamination from extraneous lipid from platelets and chylomicra.

incubated with the phospholipid emulsion for $5 \mathrm{~min}$. at $37^{\circ}$; the mixture was then ultracentrifuged and the phospholipid was resuspended in mag-

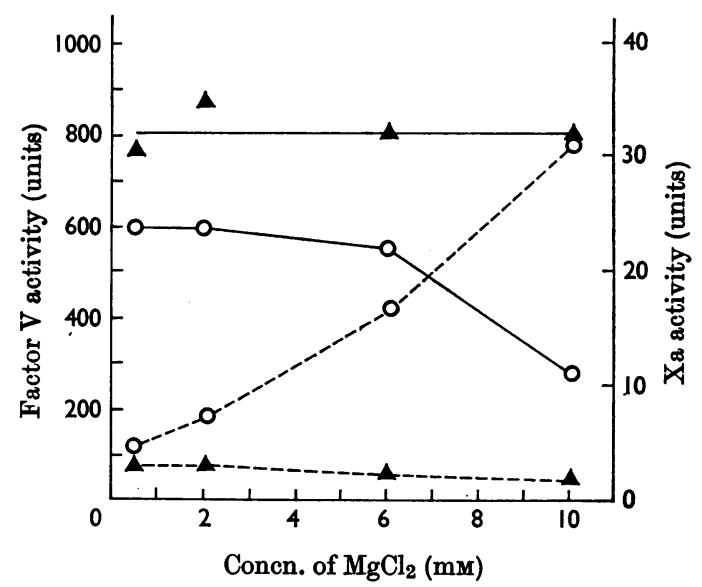

Fig. 5. Distribution of factor $\mathrm{V}$ and $\mathrm{Xa}$ activities after elution of a prothrombin-activator preparation with varying concentrations of $\mathrm{MgCl}_{2}$. $\mathrm{Xa}$ (133 units) was incubated at $37^{\circ}$ with 720 units of factor $\mathrm{V}, 0.84 \mathrm{mg}$. of Inosithin and $0.01 \mathrm{M}-\mathrm{CaCl}_{2}$; the mixture was made to $1.0 \mathrm{ml}$. with $0.112 \mathrm{M}-\mathrm{NaCl}$ buffered with $0.02 \mathrm{M}$-tris-HCl buffer, $\mathrm{pH} 7.5$. After $5 \mathrm{~min}$. the mixture was centrifuged at $85000 \mathrm{~g}$ for $20 \mathrm{~min}$. and the pellets were resuspended in $1 \mathrm{ml}$. of $\mathrm{MgCl}_{2}$ at the concentrations shown. The pellet suspension was centrifuged as before and the pellets were resuspended in $0.112 \mathrm{M}-\mathrm{NaCl}$ buffered with $0.02 \mathrm{M}$-tris$\mathrm{HCl}$, pH 7.5, containing $0.01 \mathrm{M}-\mathrm{CaCl}_{2}$. The pellets $(-)$ and $\mathrm{MgCl}_{2}$ eluates (---) were assayed for $\mathrm{Xa}(\mathrm{O})$ and factor $V(\boldsymbol{\Delta})$.

nesium chloride solutions of various concentrations. The phospholipid pellet was removed by ultracentrifugation and resuspended in $0.112 \mathrm{M}$-sodium chloride containing $0.01 \mathrm{M}$-calcium chloride buffered with $0.02 \mathrm{M}$-tris-hydrochloric acid, $\mathrm{pH} 7 \cdot 5$. The magnesium chloride supernatant and the phospholipid pellet obtained after resuspension in magnesium chloride were assayed for factor $\mathrm{V}$ and Xa. Results of such an experiment are given in Fig. 5. It will be seen that as the concentration of magnesium chloride is increased so there is an increase in the amount of $\mathrm{Xa}$ released from the phospholipid. It was found repeatedly that at low concentrations of metal ions there was usually a low recovery of $\mathrm{Xa}$. The factor $\mathrm{V}$ activity, however, remains on the phospholipid. If the concentration of $\mathrm{Mg}^{2+}$ was raised to $0.1 \mathrm{M}$ then it was possible to recover the factor $V$ activity also in the supernatant. (The yield of Xa from the lipid was increased by resuspending the phospholipid in a larger volume of eluent.)

$\mathrm{Xa}$ was incubated at $37^{\circ}$ for $5 \mathrm{~min}$. with factor $\mathrm{V}$, Inosithin and calcium chloride at a final concentration of $0.01 \mathrm{~m}$ in a final volume $1 \mathrm{ml}$. The mixture was ultracentrifuged at $4^{\circ}$ at $85000 \mathrm{~g}$ for $20 \mathrm{~min}$. 
Table 7. Distribution of ' $V a$ ' activity after elution of the prothrombin activator with magnesium chloride

In Expts. 1-3 Xa (33 units/ml.) was incubated with 1350 units of factor V/ml. and in Expts. 4-11 Xa (26.5 units/ml.) was incubated with 1350 units of factor $\mathrm{V} / \mathrm{ml}$.

\begin{tabular}{|c|c|c|c|c|c|c|c|}
\hline \multirow[b]{2}{*}{$\begin{array}{c}\text { Expt. } \\
\text { no. }\end{array}$} & \multirow[b]{2}{*}{$\begin{array}{c}\text { Magnesium } \\
\text { chloride } \\
\text { (M) }\end{array}$} & \multirow[b]{2}{*}{$\begin{array}{l}\text { Vol. of } \\
\text { eluent } \\
\text { (ml.) }\end{array}$} & \multirow[b]{2}{*}{$\begin{array}{c}\text { Inosithin } \\
(\mu \mathrm{g} . / \mathrm{ml} .)\end{array}$} & \multicolumn{4}{|c|}{ 'Va' (\%) } \\
\hline & & & & $\begin{array}{c}\text { Eluate } \\
(a)\end{array}$ & $\begin{array}{c}\text { Phospholipid } \\
\text { pellet } \\
\text { (b) }\end{array}$ & $(a)+(b)$ & $\begin{array}{c}\text { Eluate and } \\
\text { pellet } \\
\text { recombined }\end{array}$ \\
\hline 1 & 0.005 & 3 & $0 \cdot 84$ & 21 & 52 & 73 & 108 \\
\hline 2 & 0.01 & 1 & 0.84 & $5 \cdot 5$ & 48 & $53 \cdot 5$ & 82 \\
\hline 3 & 0.01 & 2 & 0.84 & 20 & 30 & 50 & 84 \\
\hline 4 & 0.01 & 2 & 0.28 & 20 & $17 \cdot 5$ & $\mathbf{3 7 \cdot 5}$ & 88 \\
\hline 5 & 0.01 & 2 & 0.21 & 21 & 21 & 42 & 94 \\
\hline 6 & 0.015 & 2 & 0.84 & $26 \cdot 5$ & 7 & $\overline{33} \cdot 5$ & 66 \\
\hline 7 & 0.01 & 2 & 0.28 & 17 & 28 & 45 & 81 \\
\hline 8 & 0.01 & 2 & 0.21 & 22 & 36 & 58 & 105 \\
\hline 9 & 0.0135 & 2 & 0.21 & 18 & $37 \cdot 5$ & $55 \cdot 5$ & 93 \\
\hline 10 & 0.010 & 2 & 0.28 & 13 & $28 \cdot 5$ & 41.5 & 73 \\
\hline 11 & 0.017 & 2 & 0.21 & 19 & $26 \cdot 5$ & $45 \cdot 5$ & 93 \\
\hline
\end{tabular}

Table 8. Distribution of factor $V$ and $X a$ activities after elution of prothrombin-activator preparations with magnesium chloride

Expts. 1-6 correspond to Expts. 1-6 of Table 8. In Expts. 7 and 8, Xa (400 units/ml.) was incubated with 720 units of factor $\mathrm{V} / \mathrm{ml}$.

\begin{tabular}{|c|c|c|c|c|c|c|c|}
\hline \multirow[b]{2}{*}{$\begin{array}{c}\text { Expt. } \\
\text { no. }\end{array}$} & \multirow[b]{2}{*}{$\underset{(\mathrm{M})}{\mathrm{MgCl}_{2}}$} & \multirow[b]{2}{*}{$\begin{array}{l}\text { Vol. of } \\
\text { eluent } \\
\text { (ml.) }\end{array}$} & \multirow[b]{2}{*}{$\begin{array}{l}\text { Inosithin } \\
(\mu \mathrm{g} . / \mathrm{ml} .)\end{array}$} & \multicolumn{2}{|c|}{ Factor V (units) } & \multicolumn{2}{|c|}{$\mathrm{Xa}_{\mathbf{a}}$ (units) } \\
\hline & & & & Eluate & $\begin{array}{l}\text { Phospholipid } \\
\text { pellet }\end{array}$ & Eluate & $\begin{array}{l}\text { Phospholipid } \\
\text { pellet }\end{array}$ \\
\hline 1 & 0.005 & 3 & 0.84 & $13 \cdot 5$ & 64 & $9 \cdot 0$ & $2 \cdot 5$ \\
\hline 2 & 0.01 & 1 & 0.84 & $1 \cdot 2$ & 52 & $3 \cdot 6$ & $3 \cdot 6$ \\
\hline 3 & 0.01 & 2 & 0.84 & $4 \cdot 8$ & 60 & $13 \cdot 2$ & $1 \cdot 3$ \\
\hline 4 & 0.01 & 2 & $0 \cdot 28$ & $1 \cdot 0$ & 52 & $8 \cdot 0$ & 0.5 \\
\hline 5 & 0.01 & 2 & 0.21 & 0.8 & $\mathbf{3 7 \cdot 5}$ & $10 \cdot 0$ & 0.5 \\
\hline 6 & 0.015 & 2 & 0.84 & $4 \cdot 8$ & 88 & $13 \cdot 2$ & 0.4 \\
\hline 7 & 0.01 & 1 & 0.84 & $4 \cdot 0$ & 296 & $360 \cdot 0$ & $40 \cdot 0$ \\
\hline 8 & 0.005 & 3 & $0 \cdot 84$ & $4 \cdot 0$ & 296 & $320 \cdot 0$ & $18 \cdot 0$ \\
\hline
\end{tabular}

as in the earlier experiments. The phospholipid pellet was resuspended in 1,2 or 3 vol. of a solution of magnesium chloride in $0.02 \mathrm{M}$-tris-hydrochloric acid, $\mathrm{pH} 7 \cdot 5$. The molarity of the $\mathrm{Mg}^{2+}$ is indicated in Table 7. The phospholipid suspension was recentrifuged as before and the phospholipid resuspended in a volume of $0.112 \mathrm{M}$-sodium chloride buffered with 0.02 M-tris-hydrochloric acid, pH 7.5, containing $0.01 \mathrm{M}$-magnesium chloride, equal to the original incubation mixture. The eluates and the resuspended phospholipid pellets were then assayed for prothrombin-converting activity of the eluate and compared with the prothrombin-converting activity obtained when the eluate and pellet fractions were recombined. For this 1 part of the resuspended pellet was added to 1,2 or 3 parts of the eluate, depending on what volume had been used in the elution, and the volume was then made to 4 parts by the addition of 1 vol. of $0.01 \mathrm{M}$ magnesium chloride.

It will be seen from Table 7 that the sum of the prothrombin-converting activity of the eluate and pellet fraction is about half that found when the two fractions were recombined.

The distribution of factor $\mathrm{V}$ and $\mathrm{Xa}$ between the eluate and pellet fractions is shown in Table 8. From this Table it is apparent that most of the factor $V$ is recovered in the pellet fraction, and that the eluate contained a large proportion of Xa. Since recombination of the fractions resulted in an increase in biological activity this suggests that both the proteins must be present together for the rapid conversion of prothrombin. This conclusion is confirmed by experiments in 
which the effect of adding the various components of the prothrombin-converting complex to prothrombin was studied.

In these experiments factor $V$, phospholipid and $\mathrm{Ca}^{2+}$ were added in various combinations to prothrombin and $\mathrm{Xa}$ and the mixtures were incubated at $37^{\circ}$ for periods up to $24 \mathrm{hr}$. Each reaction mixture was studied in duplicate or triplicate in stoppered glass tubes. The volume of each mixture was $0.5 \mathrm{ml}$. and contained $\mathrm{Xa}$ (200 or 20 units $/ \mathrm{ml}$.) and prothrombin (0.15 times bovine plasma). To this mixture was added, as indicated in Table 9, $0.1 \mathrm{ml}$. of $0.025 \mathrm{M}$-calcium chloride, $0.1 \mathrm{ml}$. of factor V (1800 units/ml.) and $0.1 \mathrm{ml}$. of an emulsion containing $5 \mu$ moles of phosphatidic acid and phosphatidylcholine in equimolar proportions. Where any of the last three reagents was omitted the volume was made up with $0.1 \mathrm{M}$-sodium chloride buffered with $0.02 \mathrm{M}$-tris-hydrochloric acid, $\mathrm{pH} 7 \cdot 5$.

At intervals $0.1 \mathrm{ml}$. samples were taken and assayed for thrombin activity. The result of each experiment is expressed as the initial rate of thrombin formation (N.I.H. units/min.) or as a relative rate of thrombin generation (Table 9). It will be seen that $\mathrm{Xa}$ slowly converts prothrombin into thrombin in the absence of $\mathrm{Ca}^{2+}$. The addition of $\mathrm{Ca}^{2+}$ doubles the rate of thrombin formation, which is greatly increased by the addition of factor $\mathrm{V}$; addition of phospholipid to mixtures containing factor $\mathrm{V}$ increased the rate of thrombin formation only fivefold when both $\mathrm{Ca}^{2+}$ and factor $\mathrm{V}$ were added. The $\mathrm{Xa}$ at the concentration used in these

Table 9. Effect of the addition of the various components of the prothrombin activator on the initial rate of thrombin formation

II, Prothrombin; V, factor V.

\begin{tabular}{|c|c|c|c|}
\hline & Mixtures & $\begin{array}{c}10^{3} \times \text { Rate of } \\
\text { thrombin } \\
\text { formation } \\
\text { (N.I.H. units/ } \\
\text { min.) }\end{array}$ & $\begin{array}{c}\text { Relative } \\
\text { rates }\end{array}$ \\
\hline & $\mathrm{II} \pm \mathrm{V}$ & 0.004 & - \\
\hline & $\mathrm{II}+\mathrm{Xa}$ & $2 \cdot 1$ & 1 \\
\hline & $\mathrm{II}+\mathrm{Xa}+\mathrm{Ca}^{2+}$ & $5 \cdot 8$ & $2 \cdot 7$ \\
\hline & $\mathrm{II}+\mathrm{Xa}+$ phospholipid & $1 \cdot 6$ & 0.7 \\
\hline & $\begin{array}{l}\mathrm{II}+\mathrm{Xa}+\text { phospholipid } \\
+\mathrm{Ca}^{2+}\end{array}$ & 290 & 138 \\
\hline & $\mathrm{II}+\mathrm{Xa}+\mathrm{V}$ & $5 \cdot 0$ & $2 \cdot 4$ \\
\hline & $\mathrm{II}+\mathrm{Xa}+\mathrm{V}+\mathrm{Ca}^{2+}$ & 1800 & 857 \\
\hline & $\mathrm{II}+\mathrm{Xa}+\mathrm{V}+$ phos & 9300 & 4428 \\
\hline
\end{tabular}

* Xa concentration used was 20 units/ml. rather than 200 units/ml. experiments had approx. $3.5 \times 10^{-3}$ N.I.H. units of thrombin activity. In this connexion, the preparations of pure factor $V$, when incubated with pure thrombin over a wide range of concentrations, did not become more reactive, but rather there was a gradual loss in biological activity.

In comparing the coagulant activity of $\mathrm{Xa}$ with that of several snake venoms it was found that tiger snake venom had an activity closely resembling that of Xa (Jobin \& Esnouf, 1966) in that the rate of prothrombin conversion is stimulated by the addition of factor $\mathrm{V}$, phospholipid and metal ions. One notable difference, however, is that the rate of prothrombin conversion was stimulated by the addition of factor $V$ without the addition of metal ions.

\section{DISCUSSION}

The results show that prothrombin is slowly converted into thrombin by the addition of $\mathrm{Xa}$, an observation which confirms the finding of Milstone (1964). The rate of thrombin formation is unlikely to be due to contamination by factor $V$, since the methods used for the isolation of prothrombin, factor $\mathrm{X}$ and $\mathrm{Xa}$ would rapidly inactivate factor $\mathrm{V}$.

On the addition of $\mathrm{Ca}^{2+}$ there was only a slight increase in the rate of thrombin formation, which was in contrast with the striking increase in reaction rate when factor $V$ was added. This activation of thrombin generation could not be explained on the basis of factor $\mathrm{V}$ being changed into an enzyme, since, if factor $\mathrm{V}, \mathrm{Xa}$, phospholipid and $\mathrm{Ca}^{2+}$ were incubated together and then the two proteins were separated, the prothrombin-converting activity of these fractions rich in factor $\mathrm{V}$ was only restored by the addition of $\mathrm{Xa}$.

Further, mixtures of $\mathrm{Xa}$, factor $\mathrm{V}$ and $\mathrm{Ca}^{2+}$ did not show any progressive increase in esterase activity, as might be expected if a new enzyme had been formed. It may also be concluded from this result that there is no increase in the reactivity of $\mathrm{Xa}$ towards synthetic substrates in the presence of factor $V$.

Though the mechanism by which factor $V$ accelerates prothrombin conversion is still unresolved it is suggested that factor $V$ either increases the reactivity of $\mathrm{Xa}$ towards its natural substrate, or the factor $\mathbf{V}$ forms a complex with prothrombin in such a way that the prothrombin becomes more susceptible to the attack by $\mathrm{Xa}$. It must be emphasized that this conclusion has been reached by using purified proteins, and does not imply that in the physiological system factor $\mathrm{V}$ and prothrombin circulate as a complex. On the contrary, the reports of factor $\mathrm{V}$ being more active in bovine serum (Ware \& Seegers, 1948), the thrombin activation of factor V (Hjort, Rapapart \& Owren, 
1955; Lewis \& Ware, 1954) and the inability to activate the purified factor $V$ with thrombin suggest that factor $V$ may be in a complex with some other substance in the plasma, from which it is released during clotting. A similar suggestion has been made by Biggs, Macfarlane, Denson \& Ash (1965) to account for increase in activity of factor VIII on exposure to thrombin. The stimulating effect of phospholipid on the rate of conversion of prothrombin is thought to be due to the localization of the interacting proteins on the phospholipid surface. The difference between those lipids which are active and those which are inactive in coagulation seems to be equated with the ability of the lipid to bind $\mathrm{Xa}$ to its surface. The bond between the protein and the phospholipid appears to be through a metal ion, since chelating agents readily elute the protein from the surface. The effect of $0.1 \mathrm{M}$-magnesium chloride in eluting the $\mathrm{Xa}$ from the surface of phospholipids is likely to be the result of the formation of an internal complex with either the phospholipid or protein.

The effect of charge, however, is not the only determinant for the efficient adsorption of $\mathrm{Xa}$ to phospholipid surface. This is clearly shown in the experiments in which dicetyl phosphoric acid was used, and it is probable that other factors such as surface pressure and charge density of the phospholipid surface are important. In this connexion van Deenen, Houtsmuller, de Haas \& Mulder (1962) have shown that the presence of unsaturated fatty acid in the phospholipid reduces the charge density at the surface.

Considering the nature of the interaction between the factor $V$ and the phospholipid reveals definite analogies with the hydrophobic type of phospholipid-proteins interaction, described by Green \& Fleisher (1963) and Richardson, Hultin \& Fleisher (1964), who showed that the structural protein of mitochondria and similar proteins extracted from the membranes of various cells are adsorbed on a variety of phospholipid micelles, regardless of the surface charge. These authors obtained evidence for the interaction between fatty acid chains of the phospholipids and the aliphatic amino acid residues, or other apolar sites of the structural protein, leaving the ionic groups of phospholipid available for ionic bond formation.

So far the interaction of the prothrombin with the lipid has not been investigated in detail, but it may be that interaction between the prothrombin and the phospholipid will be modified by the presence of factor $\mathrm{V}$. It is noteworthy that thrombin is not adsorbed on to the lipid surface.

The mechanism for the action of factor $V$ in the conversion of prothrombin proposed here is not in accordance with the scheme suggested by Davie \& Ratnoff (1964), and it may be that this form of three-protein interaction may be repeated at other stages of blood coagulation. Williams \& Norris (1966) have obtained evidence which suggests that factor VII behaves as a 'catalyst' for the activation of factor $\mathrm{X}$ by factor III, the reaction taking place on a phospholipid surface. This type of reaction mechanism may not be confined to prothrombin conversion.

The work was carried out during the tenure of a Rhodes Scholarship by F.J. We thank Mr J. R. P. O'Brien and Professor R. G. Macfarlane, F.R.S., for their advice and encouragement.

\section{REFERENCES}

Bangham, A. D., Flemans, R., Heard, D. H. \& Seaman, G. V. F. (1958). Nature, Lond., 182, 642.

Bartley, W. (1953). Biochem.J. 54, 677.

Biggs, R. \& Macfarlane, F. G. (1962). Human Blood Coagulation and its Disorders, 3rd ed., pp. 33, 377. Oxford: Blackwells Scientific Publications.

Biggs, R., Macfarlane, R. G., Denson, K. W. E. \& Ash, B. J. (1965). Brit. J. Haemat. 11, 276.

Cole, E. R., Marciniak, E. \& Seegers, W. H. (1962). Thromb. Diath. haemorrh. 8, 434.

Davie, E. W. \& Ratnoff, O. D. (1964). Science, 145, 1310.

Esnouf, M. P. \& Jobin, F. (1967). Biochem. J. 102, 660.

Esnouf, M. P. \& Williams, W. J. (1962). Biochem.J. 84, 62.

Green, D. E. \& Fleisher, S. (1963). Biochim. biophys. Acta, 70, 554 .

Hanahan, D. J., Dittmer, J. C. \& Warashina, E. (1957). J. biol. Chem. 228, 685.

Hjort, P. P., Rapaport, S. I. \& Owren, P. A. (1955). Blood, $10,1139$.

Jobin, F. \& Esnouf, M. P. (1966). Nature, Lond., 211, 873.

Kates, M. (1955). Canad. J. Biochem. Physiol. 33, 575.

Kuhn, N. J. \& Lynen, F. (1965). Biochem. J. 94, 240.

Lewis, M. L. \& Ware, A. G. (1954). Blood, 9, 520.

Milstone, J. H. (1964). Fed. Proc. 23, 742.

Richardson, S. H., Hultin, H. O. \& Fleisher, S. (1964). Arch. Biochem. Biophys. 105, 254.

van Deenen, L. L. M., Houtsmuller, U. M. T., de Haas, G. H. \& Mulder, E. (1962). J. Pharm., Lond., 14, 429. Ware, A. G. \& Seegers, W. H. (1948). Amer. J. Physiol. $152,567$.

Williams, W. J. \& Esnouf, M. P. (1962). Biochem. J. 84, 52.

Williams, W. J. \& Norris, D. G. (1966). J. biol. Chem. 241, 1847. 